\title{
MEK1/2 as a Therapeutic Target in Sickle Cell Disease
}

\author{
Rahima Zennadi* \\ Division of Hematology and Duke Comprehensive Sickle Cell Center, Department of Medicine, Duke \\ University Medical Center, North Carolina, USA
}

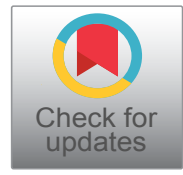

*Corresponding author: Rahima Zennadi, Division of Hematology and Duke Comprehensive Sickle Cell Center, Department of Medicine, Duke University Medical Center, Box 2615, Durham, North Carolina 27710, USA, Tel: 919-684-2135, Fax: 919-681-7688

\begin{abstract}
Identification of novel therapeutic targets has improved diagnostics and treatment of many diseases. Many innovative treatment strategies have been developed based on the newly identified biomarkers and key molecules. Most of the research focused on ways to manipulate signaling pathways by activating or suppressing them, validate new therapeutic targets for treatment, and epigenetic treatment of diseases. With the identification of aberrations in multiple growth pathways, the focus then shifted to the small molecules involved in these pathways for targeted therapy. In this communication/short review, we highlight the importance of identification of abnormal activation of the mitogen-activated protein kinase (MAPK), ERK1/2, and its upstream mediator MEK1/2, in erythrocytes in patients with sickle cell disease (SCD) critical for the adhesive interactions of these cells with the endothelium, and leukocytes promoting circulatory obstruction leading to tissue ischemia and infraction. We also discuss how targeting this signaling cascade with MEK $1 / 2$ inhibitors can reverse acute vasoocclusive crises in SCD.
\end{abstract}

\section{Keywords}

Sickle cell disease, Sickle erythrocytes, Leukocytes, MEK1/2 inhibitors, Adhesion, Endothelium

\section{List of Abbreviations}

SCD: Sickle Cell Disease; MAPK: Mitogen-Activated Protein Kinase; HbS: Hemoglobin S; VOCs: Recurrent Vasoocclusive Episodes; HbF: Fetal Hemoglobin; SS RBCs: Sickle Erythrocytes; ECM: Extracellular Matrix; EC: Endothelial Cell; ERK1/2: Extracellular Signal Regulated Kinases; MEK: Mitogen-Activated Protein Kinase Kinase; PKA: Protein Kinase A; GRK2: G Protein-Coupled Receptor Kinase 2; ROS: Reactive Oxygen Species; NSCLC: Non-Small Cell Lung Cancer

\section{Introduction}

In sickle cell disease (SCD), prevention and treatment of acute vasoocclusive crises remain a therapeutic challenge. SCD is a monogenetic disorder due to a single mutation that occurs in the globin b-chain, resulting in the formation of hemoglobin $\mathrm{S}(\mathrm{HbS})$. Recurrent vasoocclusive episodes (VOCs) contribute to morbidity and accelerated mortality, due primarily to acute pain crises and progressive irreversible ischemic end-organ damage. The pathophysiology of vasoocclusion is complex and multifactorial, involving deoxygenationdependent $\mathrm{HbS}$ polymerization and sickling leading to impaired rheology [1-4], altered cell adhesion [5-11], activation of leukocytes $[9,12]$, the endothelium [1317] and the coagulation cascade [18-20], oxidative stress [21-26], and both intracellular and extracellular signaling pathways [27-33]. While these factors may act in a positive feedback-loop to drive the pathophysiology of SCD, the gravity and the impact of each factor in promoting VOCs appears to vary. Recent studies have shown that deoxygenation of HbS-dependent rheologic alterations are suitable by themselves to significantly increase viscosity, slowing blood flow velocity at arterial oxygen tension even in the absence of inflammation, adhesion, and endothelial and leukocyte activation [3]. Multiple anti-sickling agents are currently being tested in clinical trials. The most promising ones include, SCD101, a botanical-derived drug similar to niprisan [34]. In a phase $1 \mathrm{~B}$ dose-escalation study of $26 \mathrm{HbSS}$ and $\mathrm{HbS} / \beta^{0}$ thalassemia patients, SCD-101 was well tolerated and, at higher doses, it alleviated chronic pain and fatigue, yet, this agent had no impact on Hb levels [35]. Aes-

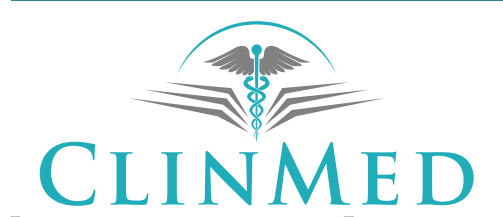

Citation: Zennadi R (2019) MEK1/2 as a Therapeutic Target in Sickle Cell Disease. Int J Blood Res Disord 6:038. doi.org/10.23937/2469-5696/1410038

Accepted: April 02, 2019: Published: April 04, 2019

Copyright: (c) 2019Zennadi R. This is an open-access article distributed under the terms of the Creative Commons Attribution License, which permits unrestricted use, distribution, and reproduction in any medium, provided the original author and source are credited. 
103 (5-hydroxymethyl-furfural) is also an anti-sickling agent undergoing clinical trials that is known to directly modify $\mathrm{Hb}$ structure [36,37]. More recently, GBT440 (a polyaromatic aldehyde) has been developed, which enhances oxygen affinity similar to Aes-103, but with higher specificity and at much lower concentrations [38]. A dose-dependent increase in $\mathrm{Hb}$ levels within 2 weeks of initiating therapy of GBT440 was accompanied by a prolonged red cell life span in SCD patients $[39,40]$. The efficacy and safety of the drug is being investigated in a double-blind multicenter phase 3 study.

Although targeting $\mathrm{HbS}$ polymerization might be a promising strategy to prevent acute pain crises, more recently, in vitro studies under hypoxic conditions have demonstrated the simultaneous and synergistic effects of adhesion and polymerization of deoxygenated $\mathrm{HbS}$ in human erythrocytes containing primarily HbSS (SS $\mathrm{RBC}$ ) on the mechanisms underlying vasoocclusive pain crisis [10]. However, abnormal adherence of SS RBCs with the endothelium can occur even under normoxic conditions and for different RBC shapes [41], and under various flow conditions [42]. Therefore, adhesion of SS RBCs to endothelium has been postulated to be a major candidate in the initiation of vasoocclusion $[41,43,44]$. In fact, more than two decades ago, Hebbel and colleagues have made critical observations: they showed that SS RBCs were abnormally adherent to cultured endothelial cells, and the degree of adhesivity shown by individual patients' RBCs correlated with their clinical disease severity [41]. We now know that SS RBCs express numerous adhesion molecules. Many erythrocyte adhesion receptors on SS RBCs have been shown in either in vitro or in/ex vivo studies to mediate adhesion of these sickle cells to either extracellular matrix (ECM), endothelial cell (EC), leukocyte or other cellular ligands $[9,29,30,32,33,45-48]$. Additionally, when SS RBCs bind to leukocytes, they cause leukocyte activation and adhesion [9]. Once leukocytes adhere to endothelial cells, they also contribute to vasoocclusion by recruiting SS RBCs to adhere to stationary leukocytes and further blockading small vessels [11]. In contrast, although normal RBCs express all the adhesion receptors expressed by mature SS RBCs, they exhibit little adhesive phenotype [29,46,48-51]. The fact that SS RBCs express a higher level of some of these receptors, such as the BCAM/Lu receptor [52], than do normal RBCs, might in part explain the adhesivity of SS RBCs. However, the degree to which receptors may be overexpressed on SS RBCs is relatively small compared to the degree to which adhesion is enhanced [52]. In addition, while SS reticulocytes express higher levels of CD36 and a4b1 integrin than do normal reticulocytes, in many experimental systems it is primarily the more mature dense sickle cells rather than the SS reticulocytes that are most adherent [53]. Several studies have attempted to prevent cell adhesion using different strategies, since the rationale of targeting adhesion is very strong.
For instance, targeting selectins with a pan-selectin inhibitor, rivipansel (GMI-1070) [54], seems to shorten the duration of acute sickle pain crises accompanied by a marked reduction in opioid use in a phase II trial [55]. Crizanlizumab (SEG101), a monoclonal antibody against P-selectin, was also efficient in lowering the rate of sickle cell-related pain crises associated with a low incidence of adverse events in a randomized double-blind study [56]. Nonetheless, the efficacy of these two agents does not appear to be superior to hydroxyurea, the only FDAapproved drug for SCD. Hydroxyurea can act as both an anti-sickling, since this drug can elevates fetal $\mathrm{Hb}(\mathrm{HbF})$ levels, but only in some SCD patients $[57,58]$, and antiadhesive agent $[58,59]$. Despite hydroxyurea reduces the frequency of vaso-occlusive episodes [60], patients with SCD remain to be treated primarily with analgesics for pain relief. Lack of real effectiveness by these antiadhesive drugs in treating VOCs when used alone, is possibly due to the fact that these agents are aimed to target the proximate, but not the route, cause of events that precipitate vasoocclusion.

Among the critical remaining questions regarding adhesion of SS RBCs to their ligands that are not fully answered, are: 1) What makes SS RBCs adherent? and 2) What makes SS RBCs capable of activating leukocytes? Our investigations have focused on signaling mechanisms that enhance SS RBC adhesion and interaction with other cells and ECM ligands, and SS RBC-induced activation of other cells. Just not long ago, we begun to understand why these adhesion receptors are more active on SS RBCs. Investigations by us and others led to the discovery that SS RBCs possess kinases that remained activated to mediate abnormal adherence of SS RBCs via phosphorylation/activation of RBC adhesion receptors, including LW (ICAM-4, CD242) blood group glycoprotein [29,31,32], CD44 [27,32], BCAM/Lutherin (Lu) [46,61-63], and a4b1 integrin [64]. So far, the identified kinases that remained active or hyper-activated in both immature and mature SS RBCs critical for adhesion of these sickle cells, are kinases of the b2-adrenergic receptor and the oxidative pathways, including the mitogen-activated protein kinases (MAPKs) known as the extracellular signal regulated kinases ERK1 and ERK2, protein kinase A (PKA), G proteincoupled receptor kinase 2 (GRK2), and the tyrosine kinases $p 72^{\text {syk }}$ and p60-c-Src [27,29,31,32,46,61-63]. The ERK1/2 pathway is a unique and critical signaling mechanism in SCD. ERK1/2 was found aberrantly active in SS RBCs, and present but inactive in normal RBCs [31]. Aberration in ERK1/2 activation occurred in both immature and mature human SS RBCs, but could not be detected in normal human reticulocytes [31,65]. In vitro and in vivo studies have revealed that abnormal human SS RBC ERK1/2 activation mediates adhesion of these sickle cells to the vascular endothelium [66,67]. Further studies have indicated that human SS RBC interaction with naïve neutrophils activates adhesion 
of naïve neutrophils to endothelial cells; this effect is also stimulated by the RBC MEK1/2 and its downstream ERK1/2 pathway [66]. More recently, we evidenced that ERK1/2 activation can be up-regulated in SS RBCs, but not in normal RBCs, by hypoxia/prolonged reoxygenation [27]. Hypoxia/prolonged reoxygenation-stimulated ERK1/2 activation creates an intra-erythrocytic positive feedback loop with reactive oxygen species (ROS) generated by NADPH oxidases, and GRK2 to mediate SS $\mathrm{RBC}$ adhesion to endothelium in vitro, and vasoocclusion in a mouse model of vasoocclusion in vivo [27]. Excessive ROS produced by HbS autoxidation within SSRBCs likely participate in the maintenance and/or increased ERK1/2 and GRK2 activities and the downstream mechanisms of sickle cell adhesion.

The MAPK cascade is a critical signal transduction pathway involved in regulation of cellular activities including proliferation [68-70], growth, differentiation $[71,72]$, apoptosis [69,70], and angiogenesis [73,74]. Protein kinases in these cascading pathways transduce extracellular signals into intracellular responses through a series of protein-protein interactions and phosphorylation. Recurrent mutations are noted in the receptor tyrosine kinases that activate this pathway [75]. In $30 \%$ of human malignancies, these signal transduction pathways are unusually activated [76]. Constitutive activation of the pathway leads to tumorigenesis, uncontrolled cell proliferation, and resistance to apoptosis [77]. Seven distinct mitogen-activated protein kinase kinase (MEK) proteins are involved in the sequential phosphorylation, upstream of the transduction pathway, and a number of target molecules have been identified. MEK1 and MEK2 are highly specific kinases that phosphorylate serine/threonine and tyrosine residues of ERK1 and ERK2. ERK1/2 are the only known substrates of MEK1/2, and are aberrantly activated in tumor cell lines. Solid tumors like melanoma, lung carcinoma, and colon carcinoma also show increased activation of ERKs [78,79], making them potential therapeutic targets for treatment. Being ATP-uncompetitive, inhibition of MEKs does not affect other kinases and thus prevents unwanted side effects.

Data in SCD now reveal a potential therapeutic benefit of the two MEK1/2 inhibitors RDEA119/BAY 869766, tested in a phase 1 clinical study in cancer, and trametinib, an FDA-approved drug for melanoma treatment. MEK1/2 inhibitors prevented the inception and/or progression of vasoocclusion in vivo in two animal models of vasoocclusion [65]. In the earlier studies, we show that the inhibitors were able to prevent the adhesion of human SS RBCs in the venules in mouse models of vasoocclusion $[66,67]$. Later on, we show that RDEA119 and trametinib given intravenous or orally were effective in reversing the adhesion of both SS RBCS and leukocytes, and established vasoocclusion in two SCD murine models of vasoocclusion, thus enabling the restoration of blood flow in the vessels [65]. The reversal effect of MEK1/2 inhibitors on SS RBC and leukocyte adhesion in SCD mouse models was rapid and efficient [65]. Moreover, these inhibitory effects did not require high doses of drug. These compounds reversed SS RBC and leukocyte adhesion at very low doses $(0.025,0.05$ and $0.1 \mathrm{mg} / \mathrm{kg}$ ) and within the first 10-30 min of drug administration; leukocyte adhesion further decreased over time [65]. Interestingly, adhesion of SS RBCs and leukocytes was reversed by the cleavage of endothelial E-selectin, P-selectin and avb3 integrin, and leukocyte CD44 and b2 integrin [65]. Our data were in agreement with previous studies showing that the MEK1/2 inhibitor PD98059 considerably reduced endothelin-1-activated neutrophil adhesion [80]. Inhibition of ERK1/2 in activated neutrophils down-regulated the expression of adhesion molecules [80]. The MEK1/2 inhibitor, U0126, was also able to attenuate cisplatin-induced renal injury by decreasing inflammation and apoptosis in mice [81].

Although the sequence of events leading to suddenly symptomatic vasoocclusion in humans with SCD is still poorly understood, the fact that MEK1/2 inhibitor therapy reverses both RBC and leukocyte adhesion triggered by inflammation in a severe sickle mouse model and an adoptive nude mouse model of vasoocclusion [65-67], portend for the potential clinical relevance of such intervention. Our data also argue that existing MEK1/2 inhibitors may be safe compounds if used acutely or for a short-term in SCD patients to treat vasoocclusion, since daily administration for 14 days of trametinib at $0.3 \mathrm{mg} / \mathrm{kg}$, a dose 12-fold higher than the lowest effective dose of RDEA119 $(0.025 \mathrm{mg} / \mathrm{kg})$, did not exacerbate anemia or caused thrombocytopenia in sickle mice [65]. Additionally, shorter-term use (7 days or less) of these drugs during acute pain crises in SCD should minimize any drug-associated side-effects [65]. Thus, despite the complexity of the pathophysiology of VOCs, MEK1/2 inhibitors may be an effective therapy in SCD, by affecting not only SS RBCs, but also leukocytes and possibly the endothelium [65-67,80,81].

Some of these MEK proteins are being evaluated as therapeutic targets in cancer clinical studies for the past few years. $\mathrm{Cl}-1040$ was the first MEK1/2 inhibitor to be used in a clinical setting and was evaluated in the treatment of non-small cell lung cancer (NSCLC), colon, pancreatic and breast cancers [82]. Although the molecule showed promising results in phase 1 with $73 \%$ inhibition of phosphorylation, it failed to have encouraging clinical activity in the phase 2 studies [82]. PD0325901, an improved version of Cl-1040 with better bioavailability and potency, also failed to meet the primary endpoints in phase 2 clinical trial [83]. Selumetinib was studied in different solid tumors and hematologic cancers in multiple phase 2 clinical studies $[84,85]$. The antitumor activity of the molecule was not significant in most of the malignancies [84,85]. Partially good responses were observed with the MEK1/2 
inhibitor GDC-0973 (XL-518, RG7421) in BRAF-mutated melanoma and BRAF-mutated pancreatic cancer $[86,87]$. Trametinib attained $10 \%$ objective responses, particularly in patients with BRAF-mutant melanoma [88]. This MEK1/2 inhibitor was then advanced to phase 3 study where a median progression free survival of 4.8 months was reported [89]. Currently, trametinib is the only FDA-approved drug for treatment of melanoma patients. Other MEK1/2 inhibitors like pimasertib (MEK162) [90-95], AZD8330 [96-98], and R05126766 [99-102] are under study, but none has demonstrated good therapeutic response of interest. One of the reasons for the failure might be that mutated proteins, like RAS and RAF, may have alternative pathways that escape the inhibitory effect of the drugs. Further, if the cancer is produced by mutations in multiple growth pathways, inhibition of one pathway may not be enough for cytotoxicity or inhibition of proliferation. In the present clinical studies, single-agent MEK1/2 inhibitor activity is shown in BRAF mutant melanoma, but stronger responses are reported when it is used in combination with BRAF inhibitors [103]. In Table 1, a list of all agents mentioned above, FDA-approved and in clinical trials, with their names, therapeutic targets, and function for treatment of VOCs in SCD, and cancer is provided.

In summary, clinical and laboratory studies validate the use of these molecular targets in the development of effective therapeutic agents for diseases like SCD, where we showed that MEK $1 / 2$ inhibitors at doses at least 20-times less than the doses tested in animal models to treat cancer, revealed to be effective and safe

Table 1: List of promising compounds in clinical trials and FDA-approved for treatment of SCD and/or cancer.

\begin{tabular}{|c|c|c|c|c|c|}
\hline Compound Name & Target & Function & Outcomes & Phase of Clinical Trial & Disease \\
\hline Hydroxyurea & $\begin{array}{l}\text { b-globin } \\
\text { gene }\end{array}$ & $\begin{array}{l}\text { Up-regulates HbF } \\
\text { expression }\end{array}$ & $\begin{array}{l}\text { Reduces the frequency of } \\
\text { vasoocclusive episodes }\end{array}$ & FDA-approved & SCD \\
\hline SCD-101 & $\mathrm{HbS}$ & Anti-sickling & $\begin{array}{l}\text { Alleviates Chronic pain } \\
\text { and fatigue }\end{array}$ & Phase 1b & SCD \\
\hline Aes-103 & $\mathrm{HbS}$ & Anti-sickling & Modified $\mathrm{Hb}$ structure & Phase 1 & SCD \\
\hline GBT440 & $\mathrm{HbS}$ & Anti-sickling & $\begin{array}{l}\text { Enhances } \mathrm{HbS} \text { oxygen } \\
\text { affinity }\end{array}$ & Double-Blind phase 3 & SCD \\
\hline $\begin{array}{l}\text { Rivipansel } \\
\text { (GMI-1070) }\end{array}$ & Selectins & Pan-selectin inhibitor & $\begin{array}{l}\text { Reduces Duration of acute } \\
\text { pain crises, and opioid use }\end{array}$ & $\begin{array}{l}\text { Randomized double- } \\
\text { Blind phase } 3\end{array}$ & SCD \\
\hline $\begin{array}{l}\text { Crizanlizumab } \\
\text { (SEG101) }\end{array}$ & $P$ selectin & $\begin{array}{l}\text { Anti-P selectin } \\
\text { monoclonal antibody }\end{array}$ & Lowers pain crises & Phase 2 & SCD \\
\hline $\begin{array}{l}\text { RDEA119/BAY } \\
869766\end{array}$ & MEK1/2 & MEK1/2 inhibitor & $\begin{array}{l}\text { Well-tolerated with some } \\
\text { clinical benefit across a } \\
\text { range of tumor types }\end{array}$ & Phase 1 & $\begin{array}{l}\text { Advanced } \\
\text { metastatic solid } \\
\text { tumor }\end{array}$ \\
\hline Trametinib & MEK1/2 & MEK1/2 inhibitor & Melanoma treatment & FDA-approved & $\begin{array}{l}\text { BRAF-mutant } \\
\text { melanoma }\end{array}$ \\
\hline $\mathrm{Cl}-1040$ & MEK1/2 & MEK1/2 inhibitor & No clinical activity & Phase 2 & $\begin{array}{l}\text { NSCLC, colon } \\
\text { pancreatic, and } \\
\text { breast cancers }\end{array}$ \\
\hline PD0325901 & MEK1/2 & MEK1/2 inhibitor & No clinical activity & Phase 2 (terminated) & $\begin{array}{l}\text { Advanced } \\
\text { breast and colon } \\
\text { cancer, and } \\
\text { melanoma }\end{array}$ \\
\hline $\begin{array}{l}\text { Selumetinib } \\
\text { (AZD6244) }\end{array}$ & MEK1/2 & MEK1/2 inhibitor & $\begin{array}{l}\text { No significant antitumor } \\
\text { activity }\end{array}$ & Phase 2 (terminated) & Breast cancer \\
\hline $\begin{array}{l}\text { GDC-0973 (XL- } \\
518, R G 7421)\end{array}$ & MEK1/2 & MEK1/2 inhibitor & Partially good responses & Phase 2 & $\begin{array}{l}\text { BRAF-mutated } \\
\text { both melanoma } \\
\text { and pancreatic } \\
\text { cancer, and } \\
\text { breast cancer }\end{array}$ \\
\hline $\begin{array}{l}\text { Pimasertib } \\
\text { (MEK162) }\end{array}$ & MEK1/2 & MEK1/2 inhibitor & & Phase 2 & $\begin{array}{l}\text { N-Ras-mutated } \\
\text { cutaneous } \\
\text { melanoma, and } \\
\text { ovarian cancer }\end{array}$ \\
\hline AZD8330 & MEK1/2 & MEK1/2 inhibitor & & Phase 1 & $\begin{array}{l}\text { Advanced } \\
\text { malignancies }\end{array}$ \\
\hline RO5126766 & MEK1/2 & MEK1/2 inhibitor & & Phase 1 & $\begin{array}{l}\text { Advanced } \\
\text { NSCLC }\end{array}$ \\
\hline
\end{tabular}

Drug's named and their targets, function, clinical benefits, and their phase in clinical trial for SCD and/or cancer treatments are presented. 
in reversing an acute vasoocclusive crisis in vivo [65]. Although many studies have been completed and some are ongoing, the clinical relevance of these molecules indicates that we are moving in the right direction.

\section{Acknowledgments}

This work was supported by the grant 1R01HL137930-01 from National Heart, Lung, and Blood Institute (NHLBI), National Institutes of Health (NIH), and a bridge funding award from Duke School of Medicine to $R Z$.

\section{Conflict-of-Interest Disclosure}

The author declares no competing financial interests.

\section{References}

1. Ferrone FA (2015) The delay time in sickle cell disease after 40 years: A paradigm assessed. Am J Hematol 90: 438-445.

2. Ferrone FA (2004) Polymerization and sickle cell disease: A molecular view. Microcirculation 11: 115-128.

3. Lu X, Wood DK, Higgins JM (2016) Deoxygenation reduces sickle cell blood flow at arterial oxygen tension. Biophys $J$ 110: 2751-2758.

4. Lu L, Li H, Bian X, Li X, Karniadakis GE (2017) Mesoscopic adaptive resolution scheme toward understanding of interactions between sickle cell fibers. Biophys $\mathrm{J}$ 113: 4859.

5. Okpala I, Daniel Y, Haynes R, Odoemene D, Goldman J (2002) Relationship between the clinical manifestations of sickle cell disease and the expression of adhesion molecules on white blood cells. Eur J Haematol 69: 135144.

6. Setty BN, Kulkarni S, Stuart MJ (2002) Role of erythrocyte phosphatidylserine in sickle red cell-endothelial adhesion. Blood 99: 1564-1571.

7. Montes RA, Eckman JR, Hsu LL, Wick TM (2002) Sickle erythrocyte adherence to endothelium at low shear: Role of shear stress in propagation of vaso-occlusion. Am J Hematol 70: 216-227.

8. Hofstra TC, Kalra VK, Meiselman HJ, Coates TD (1996) Sickle erythrocytes adhere to polymorphonuclear neutrophils and activate the neutrophil respiratory burst. Blood 87: 4440-4447.

9. Zennadi R, Chien A, Xu K, Batchvarova M, Telen MJ (2008) Sickle red cells induce adhesion of lymphocytes and monocytes to endothelium. Blood 112: 3474-3483.

10. Papageorgiou DP, Abidi SZ, Chang HY, Li X, Kato GJ, et al. (2018) Simultaneous polymerization and adhesion under hypoxia in sickle cell disease. Proc Natl Acad Sci U S A 115: 9473-9478.

11. Turhan A, Weiss LA, Mohandas N, Coller BS, Frenette PS (2002) Primary role for adherent leukocytes in sickle cell vascular occlusion: A new paradigm. Proc Natl Acad Sci U S A 99: 3047-3051.

12. Makis AC, Hatzimichael EC, Bourantas KL (2000) The role of cytokines in sickle cell disease. Ann Hematol 79: 407413.

13. Conran N, Fattori A, Saad ST, Costa FF (2004) Increased levels of soluble ICAM- 1 in the plasma of sickle cell patients are reversed by hydroxyurea. Am J Hematol 76: 343-347.

14. Solovey AA, Solovey AN, Harkness J, Hebbel RP (2001) Modulation of endothelial cell activation in sickle cell disease: A pilot study. Blood 97: 1937-1941.

15. Aslan M, Ryan TM, Adler B, Townes TM, Parks DA, et al. (2001) Oxygen radical inhibition of nitric oxide-dependent vascular function in sickle cell disease. Proc Natl Acad Sci U S A 98: 15215-15220.

16. Shiu YT, Udden MM, Mclntire LV (2000) Perfusion with sickle erythrocytes up-regulates ICAM-1 and VCAM-1 gene expression in cultured human endothelial cells. Blood 95: 3232-3241.

17. Dworkis DA, Klings ES, Solovieff N, Li G, Milton JN, et al. (2011) Severe sickle cell anemia is associated with increased plasma levels of TNF-R1 and VCAM-1. Am J Hematol 86: 220-223.

18. Qari MH, Dier U, Mousa SA (2012) Biomarkers of inflammation, growth factor, and coagulation activation in patients with sickle cell disease. Clin Appl Thromb Hemost 18: $195-200$.

19. Ataga KI, Key NS (2007) Hypercoagulability in sickle cell disease: New approaches to an old problem. Hematology Am Soc Hematol Educ Program 91-96.

20. Francis RB Jr (1991) Platelets, coagulation, and fibrinolysis in sickle cell disease: Their possible role in vascular occlusion. Blood Coagul Fibrinolysis 2: 341-353.

21. Aslan M, Canatan D (2008) Modulation of redox pathways in neutrophils from sickle cell disease patients. Exp Hematol 36: 1535-1544.

22. Nur E, Biemond BJ, Otten HM, Brandjes DP, Schnog JJ (2011) Oxidative stress in sickle cell disease; pathophysiology and potential implications for disease management. Am J Hematol 86: 484-489.

23. Rusanova I, Escames G, Cossio G, de Borace RG, Moreno B (2010) Oxidative stress status, clinical outcome, and beta-globin gene cluster haplotypes in pediatric patients with sickle cell disease. Eur J Haematol 85: 529-537.

24. Almeida CB, Franco-Penteado C, Saad ST, Costa FF, Conran N (2010) Sickle cell disease serum induces NADPH enzyme subunit expression and oxidant production in leukocytes. Hematology 15: 422-429.

25. Wood KC, Granger DN (2007) Sickle cell disease: Role of reactive oxygen and nitrogen metabolites. Clin Exp Pharmacol Physiol 34: 926-932.

26. Rice-Evans C, Omorphos SC, Baysal E (1986) Sickle cell membranes and oxidative damage. Biochem J 237: 265269.

27. MacKinney A, Woska E, Spasojevic I, Batinic-Haberle I, Zennadi R (2019) Disrupting the vicious cycle created by NOX activation in sickle erythrocytes exposed to hypoxia/ reoxygenation prevents adhesion and vasoocclusion. Redox Biol 11: 101097.

28. De Castro LM, Zennadi R, Jonassaint JC, Batchvarova M, Telen MJ (2012) Effect of propranolol as antiadhesive therapy in sickle cell disease. Clin Transl Sci 5: 437-444.

29. Zennadi R, Hines PC, De Castro LM, Cartron JP, Parise LV, et al. (2004) Epinephrine acts through erythroid signaling pathways to activate sickle cell adhesion to endothelium via LW-alphavbeta3 interactions. Blood 104: 3774-3781.

30. Zennadi R, Moeller BJ, Whalen EJ, Batchvarova M, Xu K, et al. (2007) Epinephrine-induced activation of LW-mediated 
sickle cell adhesion and vaso-occlusion in vivo. Blood 110 2708-2717.

31. Zennadi R, Whalen EJ, Soderblom EJ, Alexander SC, Thompson JW, et al. (2012) Erythrocyte plasma membranebound ERK1/2 activation promotes ICAM-4-mediated sickle red cell adhesion to endothelium. Blood 119: 1217-1227.

32. Chiou E, Zennadi R (2015) G alphas proteins activate p72(Syk) and p60-c-Src tyrosine kinases to mediate sickle red blood cell adhesion to endothelium via LW-alphavbeta3 and CD44-CD44 interactions. Int J Biochem Cell Biol 65: 40-51.

33. Brittain JE, Han J, Ataga $\mathrm{KI}$, Orringer EP, Parise LV (2004) Mechanism of CD47-induced alpha4beta1 integrin activation and adhesion in sickle reticulocytes. J Biol Chem 279: 42393-42402.

34. Wambebe CO, Bamgboye EA, Badru BO, Khamofu $\mathrm{H}$, Momoh JA, et al. (2001) Efficacy of niprisan in the prophylactic management of patients with sickle cell disease. Curr Ther Res Clin E 62: 26-34.

35. Swift R, Abdulmalik O, Chen QK, Asakura T, Gustafson K, et al. (2016) SCD-101: A New Anti-Sickling Drug Reduces Pain and Fatigue and Improves Red Blood Cell Shape in Peripheral Blood of Patients with Sickle Cell Disease. Blood 128.

36. Abdulmalik O, Safo MK, Chen Q, Yang J, Brugnara C, et al. (2005) 5-hydroxymethyl-2-furfural modifies intracellular sickle haemoglobin and inhibits sickling of red blood cells. Br J Haematol 128: 552-561.

37. Oder E, Safo MK, Abdulmalik O, Kato GJ (2016) New developments in anti-sickling agents: Can drugs directly prevent the polymerization of sickle haemoglobin in vivo? Br J Haematol 175: 24-30.

38. Metcalf B, Chuang C, Dufu K, Patel MP, Silva-Garcia A, et al. (2017) Discovery of GBT440, an Orally Bioavailable R-State Stabilizer of Sickle Cell Hemoglobin. ACS Med Chem Lett 8: 321-326.

39. Lehrer-Graiwer J, Howard J, Hemmaway CJ, Awogbade M, Telfer P, et al. (2015) GBT440, a potent anti-sickling hemoglobin modifier reduces hemolysis, improves anemia and nearly eliminates sickle cells in peripheral blood of patients with sickle cell disease. Blood 126: 542.

40. Lehrer-Graiwer J, Howard J, Hemmaway CJ, Awogbade $M$, Telfer P, et al. (2016) Long-Term Dosing in Sickle Cell Disease Subjects with GBT440, a Novel HbS Polymerization Inhibitor. Blood 128: 2488.

41. Hebbel RP, Boogaerts MA, Eaton JW, Steinberg $\mathrm{MH}$ (1980) Erythrocyte adherence to endothelium in sickle-cell anemia. A possible determinant of disease severity. $\mathrm{N}$ Engl J Med 302: 992-995.

42. Kaul DK, Fabry ME, Nagel RL (1989) Microvascular sites and characteristics of sickle cell adhesion to vascular endothelium in shear flow conditions: Pathophysiological implications. Proc Natl Acad Sci U S A 86: 3356-3360.

43. Mohandas N, Evans E (1985) Sickle erythrocyte adherence to vascular endothelium. Morphologic correlates and the requirement for divalent cations and collagen-binding plasma proteins. J Clin Invest 76: 1605-1612.

44. Kaul DK, Chen D, Zhan J (1994) Adhesion of sickle cells to vascular endothelium is critically dependent on changes in density and shape of the cells. Blood 83: 3006-3017.

45. Swerlick RA, Eckman JR, Kumar A, Jeitler M, Wick TM (1993) Alpha 4 beta 1-integrin expression on sickle reticulocytes: Vascular cell adhesion molecule-1-dependent binding to endothelium. Blood 82: 1891-1899.

46. Hines PC, Zen Q, Burney SN, Shea DA, Ataga KI, et al. (2003) Novel epinephrine and cyclic AMP-mediated activation of BCAM/Lu-dependent sickle (SS) RBC adhesion. Blood 101: 3281-3287.

47. Brittain JE, Mlinar KJ, Anderson CS, Orringer EP, Parise LV (2001) Activation of sickle red blood cell adhesion via integrin-associated protein/CD47-induced signal transduction. J Clin Invest 107: 1555-1562.

48. Matsui NM, Borsig L, Rosen SD, Yaghmai M, Varki A, et al. (2001) P-selectin mediates the adhesion of sickle erythrocytes to the endothelium. Blood 98: 1955-1962.

49. Parsons SF, Spring FA, Chasis JA, Anstee DJ (1999) Erythroid cell adhesion molecules Lutheran and LW in health and disease. Baillieres Best Pract Res Clin Haematol 12: 729-745.

50. Wautier JL, Wautier MP (2004) Erythrocytes and platelet adhesion to endothelium are mediated by specialized molecules. Clinical Hemorheol Microcirc 30: 181-184.

51. Telen MJ (2005) Erythrocyte adhesion receptors: Blood group antigens and related molecules. Transfus Med Rev 19: 32-44.

52. Zen Q, Cottman M, Truskey G, Fraser R, Telen MJ (1999) Critical factors in basal cell adhesion molecule/lutheranmediated adhesion to laminin. J Biol Chem 274: 728-734.

53. Stone PC, Stuart J, Nash GB (1996) Effects of density and of dehydration of sickle cells on their adhesion to cultured endothelial cells. Am J Hematol 52: 135-143.

54. Chang J, Patton JT, Sarkar A, Ernst B, Magnani JL, et al. (2010) GMI-1070, a novel pan-selectin antagonist, reverses acute vascular occlusions in sickle cell mice. Blood 116: 1779-1786.

55. Telen MJ, Wun T, McCavit TL, De Castro LM, Krishnamurti L, et al. (2015) Randomized phase 2 study of GMI-1070 in SCD: Reduction in time to resolution of vaso-occlusive events and decreased opioid use. Blood 125: 2656-2664.

56. Ataga KI, Kutlar A, Kanter J, Liles D, Cancado R, et al. (2017) Crizanlizumab for the Prevention of Pain Crises in Sickle Cell Disease. N Engl J Med 376: 429-439.

57. Platt OS, Orkin SH, Dover G, Beardsley GP, Miller B, et al. (1984) Hydroxyurea enhances fetal hemoglobin production in sickle cell anemia. J Clin Invest 74: 652-656.

58. Bridges KR, Barabino GD, Brugnara C, Cho MR, Christoph GW, et al. (1996) A multiparameter analysis of sickle erythrocytes in patients undergoing hydroxyurea therapy. Blood 88: 4701-4710.

59. Gambero S, Canalli AA, Traina F, Albuquerque DM, Saad ST, et al. (2007) Therapy with hydroxyurea is associated with reduced adhesion molecule gene and protein expression in sickle red cells with a concomitant reduction in adhesive properties. Eur J Haematol 78: 144-151.

60. Charache S, Terrin ML, Moore RD, Dover GJ, Barton FB, et al. (1995) Effect of hydroxyurea on the frequency of painful crises in sickle cell anemia. Investigators of the multicenter study of hydroxyurea in sickle cell anemia. $\mathrm{N}$ Engl $\mathrm{J}$ Med 332: $1317-1322$.

61. Gauthier E, Rahuel C, Wautier MP, El Nemer W, Gane P, et al. (2005) Protein kinase A-dependent phosphorylation of Lutheran/basal cell adhesion molecule glycoprotein regulates cell adhesion to laminin alpha5. J Biol Chem 280: 30055-30062. 
62. Murphy MM, Zayed MA, Evans A, Parker CE, Ataga KI, et al. (2005) Role of Rap1 in promoting sickle red blood cell adhesion to laminin via BCAM/LU. Blood 105: 3322-3329.

63. El Nemer W, Gauthier E, Wautier MP, Rahuel C, Gane P, et al. (2008) Role of Lu/BCAM in abnormal adhesion of sickle red blood cells to vascular endothelium. Transfus Clin Biol 15: 29-33.

64. El Nemer W, Wautier MP, Rahuel C, Gane P, Hermand $P$, et al. (2007) Endothelial Lu/BCAM glycoproteins are novel ligands for red blood cell alpha4beta1 integrin: Role in adhesion of sickle red blood cells to endothelial cells. Blood 109: 3544-3551.

65. Zhao Y, Schwartz EA, Palmer GM, Zennadi R (2016) MEK1/2 inhibitors reverse acute vascular occlusion in mouse models of sickle cell disease. FASEB J 30: 11711186.

66. Zennadi R (2014) MEK Inhibitors, novel anti-adhesive molecules, reduce sickle red blood cell adhesion in vitro and in vivo, and vasoocclusion in vivo. Plos One 9: e110306.

67. Zennadi R (2014) MEK Inhibitors, novel anti-adhesive molecules, reverse sickle red blood cell adhesion and vasoocclusion in vivo. Blood 124: 739.

68. Zhao L, Zhang T, Geng H, Liu ZQ, Liang ZF, et al. (2018) MAPK/AP-1 pathway regulates benzidine-induced cell proliferation through the control of cell cycle in human normal bladder epithelial cells. Oncol Lett 16: 4628-4634.

69. Guo J, Qiu X, Zhang L, Wei R (2018) Smurf1 regulates macrophage proliferation, apoptosis and migration via JNK and p38 MAPK signaling pathways. Mol Immunol 97: 2026.

70. Xu T, Gu J, Li C, Guo X, Tu J, et al. (2018) Low-intensity pulsed ultrasound suppresses proliferation and promotes apoptosis via p38 MAPK signaling in rat visceral preadipocytes. Am J Transl Res 10: 948-956.

71. Zhang Y, Gao F, Tang Y, Xiao J, Li C, et al. (2018) Valproic acid regulates Ang II-induced pericyte-myofibroblast transdifferentiation via MAPK/ERK pathway. Am J Transl Res 10: 1976-1989.

72. Yang S, Guo L, Su Y, Wen J, Du J, et al. (2018) Nitric oxide balances osteoblast and adipocyte lineage differentiation via the JNK/MAPK signaling pathway in periodontal ligament stem cells. Stem Cell Res Ther 9: 118.

73. Sangpairoj K, Vivithanaporn $P$, Apisawetakan $S$, Chongthammakun S, Sobhon P, et al. (2017) RUNX1 Regulates Migration, Invasion, and Angiogenesis via p38 MAPK Pathway in Human Glioblastoma. Cell Mol Neurobiol 37: 1243-1255.

74. Kumar D, Kumar S, Gorain M, Tomar D, Patil HS, et al (2016) Notch1-MAPK signaling axis regulates CD133(+) cancer stem cell-mediated melanoma growth and angiogenesis. J Invest Dermatol 136: 2462-2474.

75. Neiswender JV, Kortum RL, Bourque C, Kasheta M, Zon LI, et al. (2017) KIT Suppresses BRAF(V600E)Mutant Melanoma by Attenuating Oncogenic RAS/MAPK Signaling. Cancer Res 77: 5820-5830.

76. Hoshino R, Chatani Y, Yamori T, Tsuruo T, Oka H, et al. (1999) Constitutive activation of the 41-/43-kDa mitogenactivated protein kinase signaling pathway in human tumors. Oncogene 18: 813-822.

77. Imperial R, Toor OM, Hussain A, Subramanian J, Masood A (2019) Comprehensive pancancer genomic analysis reveals (RTK)-RAS-RAF-MEK as a key dysregulated pathway in cancer: Its clinical implications. Semin Cancer Biol 54: 14-28.

78. Iverson C, Larson G, Lai C, Yeh LT, Dadson C, et al. (2009) RDEA119/BAY 869766: A potent, selective, allosteric inhibitor of MEK $1 / 2$ for the treatment of cancer. Cancer Res 69: 6839-6847.

79. Tegnebratt T, Ruge E, Bader S, Ishii N, Aida S, et al. (2014) Evaluation of efficacy of a new MEK inhibitor, RO4987655, in human tumor xenografts by [(18)F] FDG-PET imaging combined with proteomic approaches. EJNMMI Res 4: 34.

80. József L, Khreiss T, Fournier A, Chan JS, Filep JG (2002) Extracellular signal-regulated kinase plays an essential role in endothelin-1-induced homotypic adhesion of human neutrophil granulocytes. Br J Pharmacol 135: 1167-1174.

81. Jo SK, Cho WY, Sung SA, Kim HK, Won NH (2005) MEK inhibitor, U0126, attenuates cisplatin-induced renal injury by decreasing inflammation and apoptosis. Kidney Int 67 : 458-466.

82. Rinehart J, Adjei AA, Lorusso PM, Waterhouse D, Hecht JR, et al. (2004) Multicenter phase II study of the oral MEK inhibitor, $\mathrm{Cl}-1040$, in patients with advanced non-small-cell lung, breast, colon, and pancreatic cancer. J Clin Oncol 22: 4456-4462.

83. Haura EB, Ricart AD, Larson TG, Stella PJ, Bazhenova L, et al. (2010) A phase II study of PD-0325901, an oral MEK inhibitor, in previously treated patients with advanced nonsmall cell lung cancer. Clin Cancer Res 16: 2450-2457.

84. Hayes DN, Lucas AS, Tanvetyanon T, Krzyzanowska MK, Chung $\mathrm{CH}$, et al. (2012) Phase II efficacy and pharmacogenomic study of Selumetinib (AZD6244;ARRY-142886) in iodine-131 refractory papillary thyroid carcinoma with or without follicular elements. Clin Cancer Res 18: 2056-2065.

85. O'Neil BH, Goff LW, Kauh JS, Strosberg JR, Bekaii-Saab TS, et al. (2011) Phase II study of the mitogen-activated protein kinase $1 / 2$ inhibitor selumetinib in patients with advanced hepatocellular carcinoma. J Clin Oncol 29: 23502356.

86. Hoeflich KP, Merchant M, Orr C, Chan J, Den Otter D, et al. (2012) Intermittent administration of MEK inhibitor GDC-0973 plus PI3K inhibitor GDC-0941 triggers robust apoptosis and tumor growth inhibition. Cancer Res 72: 210219.

87. Junttila MR, Devasthali V, Cheng JH, Castillo J, Metcalfe C, et al. (2015) Modeling targeted inhibition of MEK and PI3 kinase in human pancreatic cancer. Mol Cancer Ther 14: 40-47.

88. Infante JR, Fecher LA, Falchook GS, Nallapareddy S, Gordon MS, et al. (2012) Safety, pharmacokinetic, pharmacodynamic, and efficacy data for the oral MEK inhibitor trametinib: A phase 1 dose-escalation trial. Lancet Oncol 13: 773-781.

89. Flaherty KT, Robert C, Hersey P, Nathan P, Garbe C, et al. (2012) Improved survival with MEK inhibition in BRAFmutated melanoma. N Engl J Med 367: 107-114.

90. Ascierto PA, Schadendorf D, Berking C, Agarwala SS, Van Herpen CM, et al. (2013) MEK162 for patients with advanced melanoma harbouring NRAS or Val600 BRAF mutations: A non-randomised, open-label phase 2 study. Lancet Oncol 14: 249-256.

91. Küsters-Vandevelde $H V$, Willemsen $A E$, Groenen $P J$, Küsters B, Lammens M, et al. (2014) Experimental treatment of NRAS-mutated neurocutaneous melanocytosis with MEK162, a MEK-inhibitor, Acta Neuropathol Commun 2: 41. 
92. Bendell JC, Javle M, Bekaii-Saab TS, Finn RS, Wainberg ZA, et al. (2017) A phase 1 dose-escalation and expansion study of binimetinib (MEK162), a potent and selective oral MEK1/2 inhibitor. Br J Cancer 116: 575-583.

93. Narayan RS, Gasol A, Slangen PLG, Cornelissen FMG, Lagerweij T, et al. (2018) Identification of MEK162 as a radiosensitizer for the treatment of glioblastoma. Mol Cancer Ther 17: 347-354.

94. Jin L, Jin MH, Nam AR, Park JE, Bang JH, et al. (2017) Anti-tumor effects of NVP-BKM120 alone or in combination with MEK162 in biliary tract cancer. Cancer Lett 411: 162170.

95. Maiti A, Naqvi K, Kadia TM, Borthakur G, Takahashi K, et al. (2019) Phase II Trial of MEK inhibitor Binimetinib (MEK162) in RAS-mutant acute myeloid leukemia. Clin Lymphoma Myeloma Leuk 19: 142-148.e1.

96. Cohen RB, Aamdal S, Nyakas M, Cavallin M, Green D, et al. (2013) A phase I dose-finding, safety and tolerability study of AZD8330 in patients with advanced malignancies. Eur J Cancer 49: 1521-1529.

97. Yao Y, Bian YP, Xia DD, Pan B, Niu MS, et al. (2014) Effect of AZD8330 on proliferation and apoptosis of multiple myeloma cells. Zhongguo Shi Yan Xue Ye Xue Za Zhi 22: 1311-1315.

98. Feng K, Wang C, Zhou H, Yang J, Dong L, et al. (2015) Effect of ERK1/2 inhibitor AZD8330 on human Burkitt's lymphoma cell line Raji cells and its mechanism. Zhonghua Xue Ye Xue Za Zhi 36: 148-152.

99. Martinez-Garcia M, Banerji U, Albanell J, Bahleda R, Dolly S, et al. (2012) First-in-human, phase I dose-escalation study of the safety, pharmacokinetics, and pharmacodynamics of RO5126766, a first-in-class dual MEK/RAF inhibitor in patients with solid tumors. Clin Cancer Res 18: 4806-4819.

100. Ishii N, Harada N, Joseph EW, Ohara K, Miura T, et al. (2013) Enhanced inhibition of ERK signaling by a novel allosteric MEK inhibitor, CH5126766, that suppresses feedback reactivation of RAF activity. Cancer Res 73: 4050-4060.

101. Honda K, Yamamoto N, Nokihara H, Tamura $\mathrm{Y}$, Asahina H, et al. (2013) Phase I and pharmacokinetic/ pharmacodynamic study of R05126766, a first-inclass dual Raf/MEK inhibitor, in Japanese patients with advanced solid tumors. Cancer Chemother Pharmacol 72: $577-584$

102. Wada M, Horinaka M, Yamazaki T, Katoh N, Sakai T (2014) The dual RAF/MEK inhibitor CH5126766/ RO5126766 may be a potential therapy for RAS-mutated tumor cells. PloS One 9: e113217.

103. Friday BB, Yu C, Dy GK, Smith PD, Wang L, et al. (2008) BRAF V600E disrupts AZD6244-induced abrogation of negative feedback pathways between extracellular signalregulated kinase and Raf proteins. Cancer Res 68: 61456153. 